\title{
Itinéraires Itinéraires
}

Littérature, textes, cultures

2019-2 et 3 | 2019

Corps masculins et nation : textes, images, représentations

\section{Queer and Asian: Redefining Chinese American Masculinity in The Wedding Banquet (Ang Lee, 1993) and Red Doors (Georgia Lee, 2006)}

Queer et asiatique : redéfinitions de la masculinité sino-américaine dans Un garçon d'honneur (Ang Lee, 1993) et Red Doors (Georgia Lee, 2006)

Juliette Ledru

\section{OpenEdition}

Journals

Electronic version

URL: http://journals.openedition.org/itineraires/7067

DOI: 10.4000/itineraires.7067

ISSN: 2427-920X

Publisher

Pléiade

Electronic reference

Juliette Ledru, «Queer and Asian: Redefining Chinese American Masculinity in The Wedding Banquet (Ang Lee, 1993) and Red Doors (Georgia Lee, 2006) », Itinéraires [Online], 2019-2 et 3 | 2019, Online since 13 December 2019, connection on 15 December 2019. URL : http://journals.openedition.org/ itineraires/7067 ; DOI : 10.4000/itineraires.7067

This text was automatically generated on 15 December 2019.

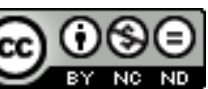

Itinéraires est mis à disposition selon les termes de la licence Creative Commons Attribution - Pas d'Utilisation Commerciale - Pas de Modification 4.0 International. 


\title{
Queer and Asian: Redefining Chinese American Masculinity in The Wedding Banquet (Ang Lee, 1993) and Red Doors (Georgia Lee, 2006)
}

\author{
Queer et asiatique : redéfinitions de la masculinité sino-américaine dans Un \\ garçon d'honneur (Ang Lee, 1993) et Red Doors (Georgia Lee, 2006)
}

Juliette Ledru

1 Yellow Peril, goodwill ambassadors, China dolls, model minorities... Chinese Americans have been subjected to stereotypes ever since the nineteenth century. It was only in the 1960s-70s, in the wake of the Civil Rights Movement, that they could make their voices heard and take a stand against exclusive assimilation (Alba and Nee [2003] 2005). However, until the 1990s, Chinese American literary voices dwelled on the topos of the cultural and generational gap (for instance Amy Tan's The Joy Luck Club, which inspired the movie adaptation).

2 Some fiction authors as well as movie directors decided to tackle more complex and marginal themes while resorting to the said topos. Ang Lee's The Wedding Banquet is part of a trilogy of Taiwanese domestic comedies (Pushing Hands, 1992; The Wedding Banquet, 1993; Eat Drink, Man Woman, 1994). Its main protagonists, Wai Tung and Simon, are a happy and strong gay couple, with a successful professional life. Wai Tung is an entrepreneur and Simon a physiotherapist. The only issue they are facing is the fact Wai Tung has not told his parents he was gay. In Taiwan, they endeavor to find him a suitable wife, and regularly send him letters and forms to fill. In order to put an end to this pressure, Wai Tung tells his parents he is going to marry Wei Wei, a young immigrant artist from mainland China, whom he met in New York. This situation becomes out of hand when Wai Tung's parents inform him that they will come to New York for his wedding. In the movie Red Doors, the theme of homosexuality is less prominent, although the queer storyline permeates the rest of the plot. Julie is the closeted lesbian daughter of Ed Wong, who has just recently retired. She has two 
sisters, Sam, a successful businesswoman and Katie, a teenager fond of rap music and hip-hop dancing. Ed is the most intriguing of all characters: a suicidal personality who one day leaves his family to enter a Buddhist temple and meditate.

Those two movies deconstruct ethnic stereotypes, but only on the surface. The more complex objective is to shift the paradigm in place: what is marginal and what is normative is no longer based on an ethnic paradigm. Here, it is expressed through the prism of sexualities and masculinities. The characters are successfully assimilated into mainstream America. Nevertheless, they fight against the normative construct of American and Chinese societies and systems. By doing so, the definitions of what it means to be a man, to be Chinese, to be American, a father, in other words, identities, are redefined along the axis of sexualities and the construction of masculinities.

In this article, we explore Chinese American masculinity as a site of negotiation and resistance to social and cultural representations. To do so, we first come back on the legislative and symbolic emasculation of Chinese Americans. Then, we use the concept of "queer" in its most political sense. Indeed, defined by David Eng and Alice Hom, queer is "a political practice based on transgressions of the norm and normativity rather than a straight/gay binary of heterosexual/homosexual identity" (Eng and Hom 1998: 1).

5 Firstly, in his movie The Wedding Banquet, Ang Lee tackles the theme of Chinese Americanness through the prism of Wai Tung. His closeted life to his parents but out and proud lifestyle in New York allows us to explore the imagined dimension of masculinity both from a Chinese standpoint and from a mainstream American one, and we thus study how Ang Lee uses this queer storyline in order to offer new social and cultural perspectives.

On the other hand, the concept of queer can be used as a theoretical tool which allows us to explore Asian American racial formation, masculinities, as well as the failure of Asian American patriarchy. This is done through the prism of Georgia Lee's Wongs, a very assimilated and dysfunctional family. Our queer analysis focuses on Ed, the suicidal patriarch of the family. We intend to show that this movie offers a queering of ethnicity ${ }^{1}$ which allows Georgia Lee to denounce the normative and assimilationist pressure American society puts on its hyphenated citizens.

\section{The Heavy Burden of Orientalism: Racial Castration as a Means of Defining the American Nation-State ${ }^{2}$}

\section{International Relations and Domestic Legislative Measures: Feminized Asian Nations and a Gendered and Emasculated Male Chinese Community}

During the eighteenth and then nineteenth century, the Western world construed a representation of the Orient as inferior to the Occident, Westerners turned into lifesaver and superior. This coincided at the time with a Christian vision at the heart of all missions to the East. Consequently, the representation of the Asian population was mostly based on reports written by some of the first Western persons to meet Chinese people, missionaries who told more or less romanced tales. In those writings, Chinese men were said to be exotic and immoral. In the American context, the political ideology of the Manifest Destiny-an international expansion justified as a religious expedition- 
was clearly entangled with the Orientalist discourse, as Karen J. Leong explains in her work The China Mystique:

[The] orientalist discourse took root and thrived in the "virgin soil" of North America. The developing United States began incorporating distorted notions of "the Orient" and "Asiatics" within its social and political formations well before the arrival of Chinese immigrants in the nineteenth century. During that century an orientalist aesthetic helped justify American nation-building beyond the borders of the United States, an ideology that crystallized in 1845 as Manifest Destiny. It claimed a divine mandate for the United States to dominate culturally, economically, and politically and captured the ambitions of many Euro-Americans. (Leong 2005: 7)

In the United States, the first Chinese immigrants appeared in 1848. The calls of the Gold Rush in San Francisco, in addition to the need for a cheap labor force in the construction of the transnational railroad system, partook in the push and pull process which attracted many immigrants from the other side of the Pacific Ocean. Nonetheless, in the midst of the economic depression of the 1870s, the Chinese, a cheap labor force, were deemed responsible for the economic depression and the unemployment of countless other workers.

It was in this context that the legislation partook in the construction of a definition of Americanness as masculine, exclusive and anti-Chinese. In 1875, the Page Law was passed, denying entry on US soil to Chinese women, suspected of all being prostitutes. ${ }^{3}$ Then, in 1882, the Chinese Exclusion Act was enacted, barring entry to all Chinese laborers. The Chinese were also denied entitlement to American citizenship. Deprived of rights, women, family and voice, the Chinese community was construed as a bachelor community, on the outskirts of the U.S. nation-state, and its men were legislatively and symbolically emasculated. In fact, in the wake of the Chinese Exclusion Act, the Chinese population on US soil amounted to a group of single men, either bachelors who were denied the right to marry an American woman, or married Chinese men whose wives (and children) were left in China, and to whom they would send money. As Rachel Leng explains in her article "Calling All 'Dragon Ladies,' 'China Dolls,' and 'Lotus Blossoms”':

As these Chinese immigrants gained increasing success and posed a threat to the prosperity of white Americans, exclusionary immigration laws such as the Chinese Exclusion Act of 1882 and the National Origins Act of 1924 were subsequently enacted. These racially-based immigration policies were biased against Chinese men and women in order to control and eliminate the Chinese population in America (Chan 1991). They drastically transformed traditional family and community structures and heavily influenced gender role dynamics in the newly developing Chinese American community (Gyiori 1998; Lai 1988). (Leng 2013: 17).

Some of the Chinese men who received American citizenship sold fraudulent documentations to Chinese people willing to emigrate, documents stating they had a son in China. This would allow illegal immigrants to purchase such documents and state they were entitled to come to the United States. This "slot" or vacant seat on a ship bound to US shores gave way a new immigration of Chinese men, nicknamed "paper sons." As for the "paper fathers," this situation illustrated their symbolic emasculation and a factitious fatherhood. As a consequence, the confluence of the Page Act with the Chinese Exclusion Act led to a dialectic relation between ethnicity and sex as far as the Chinese population on US soil was concerned. As such, racial politics in the United States were entangled with sexual politics. ${ }^{4}$

9 During the first half of the twentieth century, racial stereotyping was reinforced through literary means. As for the representation of male characters, in Britain, Sax 
Rohmer created an evil character, $\mathrm{Fu}$ Manchu, whose life is dedicated to the destruction of the Western world. For instance, in the first novel, The Insidious Dr. Fu Manchu (1913), Fu Manchu is depicted as "the yellow peril incarnate in one man" (Rohmer [1913] 1994: 16), with "a face like Satan" (16), nothing but "cruel cunning of an entire Eastern race" (16). On the other side of the Atlantic Ocean, American writer Earl Derr Biggers created Charlie Chan in 1925, another stereotypical Chinese character, who conveys a contrary vision: that of the servile and harmless, but still unassimilable Chinese. As Benson Tong wrote: "both Fu Manchu and Charlie Chan shared the burden of alienness-Fu Manchu was Yellow Peril gone wild, and Chan was Yellow Peril contained" (Tong 2000: 64).

This institutional emasculation, reinforced with racial and sexist stereotypes, enabled American masculinity to be construed as white, Anglo-Saxon and especially non-Asian. Whether a yellow peril, a paper son, or an inoffensive "Chinaman," Chinese men carried with them everything that was viewed as non-American and thus nonmasculine. ${ }^{5}$ It may well be noted that those stereotypes also applied to other groups of Asian immigrants, but we can underline the fact that contrary to Chinese immigrants, Japanese immigrants for instance came to work in the field of agriculture and settled as families. Chinese laborers, once the national railway system completed, were limited to jobs deemed feminine (laundry, cooking).

\section{0s: Cultural Politics and Pen War. Cultural Redefinitions of Asian Masculinity}

During the 1930s until the end of the Second World War, relationships between China and the United States improved. China, previously deemed a weak nation, became Japan's fierce enemy in 1937 after being invaded, and thus a precious ally to the American government when Japan bombed Pearl Harbor in 1941. The transformation of China from alien to ally (Leong 2005: 164) participated in the positive evolution of the representation of Chinese and Chinese American people in the eyes of the American people. In 1966, a new stereotype, supposedly positive, was coined to refer to Japanese and Chinese Americans: sociologist William Petersen described them as the "model minority," (Petersen 1966) members of ethnic minorities who have become fully assimilated into the American society. This stereotype was mainly built as a means of maintaining invisible the Asian community and silent its claims. ${ }^{6}$ We can refer here for instance to a cover of Time magazine (August 31, 1987), ${ }^{7}$ illustrating this stereotype, according to which Asian Americans are "whiz kids," math geniuses, calm, inoffensive. This change in stereotyping occurred in the context of the 1960s, which witnessed the decline of white hegemony in the USA and a first taking into account of minority discourses, needs and rights. In this context, new voices came to be heard: ethnic minorities', LGBTs', women's. The objective was to no longer remain on the margins of the American mainstream society but to claim America, to claim their rights.

In this context, the notion of masculinity was at the heart of minority discourses and conflicts. Indeed, during the 1960s and 1970s, a number of women wrote and published fiction works telling stories from the perspective of women from minority ethnic groups. However, writers like Frank Chin opposed this literature, complaining that these women writers did not honor Asian men and that they were feminizing the minority discourse and belittling men. In his pioneer anthology of Asian American 
writing, Aiiieeeee! An Anthology of Asian American Writers (1974), Chin calls for a literature that would be mainly masculine, Chinese and Japanese, heterosexual, illustrating the plight of symbolically emasculated men:

The Asian Americans here are elegant or repulsive, angry and bitter, militantly anti-white or not, not out of any sense of perversity or revenge but out of honesty. America's dishonesty-and its racist white supremacy passed off as love and acceptance-has kept seven generations of Asian Americans off the air, off the streets, and praised us for being Asiatically no-show. (Chin et al. 1974: xix-xx)

Chin was clearly an opponent to any representation of Asians as compliant, subdued and silent. These adjectives were implied in the "model minority" stereotype, which was just another homogeneous appellation imposed upon by mainstream society, the same way the "yellow peril" and the "Charlie Chan" stereotypes were perpetuated as a means of demonizing and inferiorizing Chinese Americans. Thus Asian Americans were deprived of their masculinity-inoffensive, silent, and subdued. This was voiced by people like Frank Chin, even though with hindsight, his allegedly inclusive anthology is nothing but the aggregate of androcentric Asian American literature which is thus ethnicized and gendered, especially when it comes to the relationship between the sexes. Amy Sueyoshi condemns his position in her work "Queer Asian American Historiography": "Frank Chin, Jeffrey Paul Chan, and their yellow brethren no doubt dissuaded many from even touching queer topics with their homophobic diatribes of the 1970s" (2016: 267). If the 1960s mark a shift in American politics and cultural representations-"claiming America"-, claiming America thus came with its share of contradictions, as expressed in the pen war between feminist Chinese American writer Maxine Hong Kingston and Frank Chin.

In the face of such misogynist and often homophobic definitions of masculinity, queer Asian Americans meet the difficult challenge to conform neither to the Chinese identity that American representations offer, nor to one envisioned by Asian nationalists such as Frank Chin.

\section{Negotiating while Resisting: The Wedding Banquet (1993) as a Critical Exploration of the Transnational Imagined Dimensions of Masculinities ${ }^{8}$}

\section{Humor and Masquerade: the Theatricality of Masculinity and Heteronorms}

On the surface, Wai Tung appears to be the embodiment of the model minority stereotype. Indeed, he represents the immigrant ideal: a successful entrepreneur, speaking fluent English, living away from Chinatown, in Manhattan. His Caucasian partner Simon calls him "such a disgusting yuppie," acronym for young urban professional. Wai Tung is truly assimilated into the American mainstream society. However, his homosexuality leaves him on the margins of the dominant society, more so when he remains closeted to his parents. It is this contradiction that informs on the notion of masculinity in the US but also in the eyes of conservative Chinese parents. This is the contradiction which we will explore and analyze here. 
15 Firstly, this movie uses stereotypes in order to better debunk them. The technique is one of reverse stigmatization, a concept developed by sociologist Erving Goffman in his work Stigma: Notes on the Management of Spoiled Identity:

One of these groups is the aggregate formed by the individual's fellow-sufferers. The spokesmen of this group claim that the individual's real group, the one to which he naturally belongs, is this group. All the other categories and groups to which the individual necessarily also belongs are implicitly considered to be not his real ones; he is not really one of them. The individual's real group, then, is the aggregate of persons who are likely to have to suffer the same deprivations as he suffers because of having the same stigma; his real "group," in fact, is the category which can serve as his discrediting. (Goffman [1963] 1986: 112-13)

Goffman calls reverse stigmatization the fact that one group or one member of a group may appropriate the stigma (which can come as an insult) in order to counter its effect. Before we analyze the reversal of situations, we may notice that Ang Lee first opposes the stereotype of the Asian gay man as effeminate and passive by introducing Wai Tung at the very beginning of the movie as a successful, sporty and assertive young man. As his ambition is to explore the tensions at the intersection of sexuality, ethnicity and intergenerational relationships, Lee reverses stigmatization through several techniques: observational humor (Leung 2008: 31), masquerade and theatricality. In the movie, two situations denote these techniques: degaying one's apartment and one's masculinity, and the performance of a wedding.

\section{Degaying One's Apartment}

In order to relieve his parents from their angst concerning their fear of not having grandchildren, Wai Tung intends to marry Wei Wei. Once his parents tell him they will come to his wedding, he has no other choice than transform his lifestyle into the appearance of what it means to be Chinese American and heterosexual. In other words, Wai Tung decides to perform the ideal of masculinity for his parents and to recreate in New York the closet he had previously come out from. The closet is a metaphor developed in the 1990s by queer theorists such as Eve Kosofsky Sedgwick in her seminal work Epistemology of the Closet:

"Closetedness" itself is a performance initiated as such by the speech act of a silence-not a particular silence, but a silence that accrues particularity by fits and starts, in relation to the discourse that surrounds and differentially constitutes it. (Sedgwick [1993] 2007: 3)

The closet functions as a metaphor for the world in which homosexuals live when they are forced to hide their sexual orientation and perform a heterosexual identity. In order to perform such Chinese American heterosexual masculinity, Wai Tung transforms his apartment into a heterosexual pad.

This heteronormativisation of his apartment, highly theatrical, highlights the performance of what it means to be a man in a heteronormative world. This "degaying," (Feng 2002a: 186), enables to re-create both a heterosexual and a supposedly authentic Chinese apartment. First heterosexual, with picture frames of the couple Simon-Wai Tung replaced with pictures of Wei Wei and Wai Tung; a picture of Wai Tung in a military uniform replaces that of a joyful bare-chested gay Wai Tung. Chinese authenticity is conveyed through the use of Chinese calligraphy adorning the walls of the apartment. In this masquerade, there is barely any room left for Simon, who is turned into the nice roommate, even though the fact he is a bachelor makes him 
appear marginal in the eyes of Wai Tung's parents. It is quite ironic to notice that previously, Simon was the one who cooked Chinese dishes, while in this new context, Wei Wei becomes the dutiful cook and housewife. Authenticity is thus denounced as something artificial, and heterosexuality and Chinese American masculinity are made to appear as social constructs. Through the debunking and denouncing of such codes, Ang Lee here underlines the assimilationist and alienating power of norms. Assimilation of family expectations lead Wai Tung to pretend being heterosexual, thus turning his back-though temporally-on his partner, Simon. Alienation comes in the wake of such assimilation and closetedness. Wai Tung alienates himself from his parents, as he hides his sexual orientation and lies to them; he alienates himself from Simon, relegating him to the part of a landlord. And he alienates himself, no longer being true to his feelings. This performance of heteronormativity is nonetheless conveyed with observational humor, and the theatricality is built thanks to metafictional cues.

For instance, theatricality is conveyed through the character of Simon, who acts as a true stage director and tells Wei Wei every single detail about Wai Tung's habits: "He showers in the morning unless he goes to the gym," "He wears jockey, but he sleeps in boxers" for instance. When Wai Tung and Simon are at home, they discuss their first day as two heterosexual roommates. Their conversation works in the form of theatrical off-stage comments: "How was my performance on the first day?" asks Simon, to which Wai Tung replies: "About a B-plus." In a second scene, Wai Tung asserts: "The final act. And then they're out here." The remarks shed light on the characters' critical stance against heteronormativity. They are fully aware that they are acting heterosexual, they are pretending living a normative lifestyle, and their apartment has become the stage on which heteronormativity and masculinity are played.

\section{The Performance of the Wedding}

Wai Tung's masquerade and his simulacra of a wedding offer an insightful vision of society's heteronormativity. Wai Tung and Wei Wei get married in order to relieve the Gaos' angst of filiation. They also marry to provide Wei Wei with a green card. This marriage is nothing but the means of answering family expectations and in this context, the wedding ceremony is denounced as a real theatrical performance. At the town hall, Wai Tung and Wei Wei are presented as comedians who do not know where to stand on the stage, and who do not know their script. Wei Wei, overwhelmed, stammers and cannot follow the script, ending up telling the complete opposite of the vows she is supposed to tell: "Wee-Wee... Wee-Wee... holding to have... husband... mine... better and richer... no poorer... till sickness and death." What is more, the officer who is about to marry them also provides cues to the artificiality of the event. He asks them to shift seats, telling Wai Tung he is supposed to stand on the outside, which explicitly recalls Wai Tung's homosexuality and his marginal status. These remarks and situations, no matter how awkward they turn our characters, bring comic relief to the scene. The Gao parents are devastated by the fact that there will not be a wedding, just a plain civil marriage, and they are making a wry face at the ceremony. Not a single character appears to be happy, or just satisfied that Wai Tung marries. Simon is the sole one trying his best to turn this ceremony into something positive. Wai Tung's mother pretends to smile as he takes a picture of the Gao parents. 
21 Moreover, heteronormativity is exposed as an ideal which is impossible to reach. This is visible in the reaction of Wai Tung's parents when he first tells them there will not be any wedding, just a simple marriage at the town hall: their deepest wish was to marry their son "Chinese style," that is to say with a grand banquet. When their son tells them there is not going to be any festivity, guest or banquet, Ma collapses and cries. In the end, it is not enough to have their son answer their heterosexual expectations, what they want is the performance of the norm. When Wai Tung eventually organizes a banquet for his parents, the various wedding festivities shed light on artificial heterosexual norms. For instance, before the wedding's banquet, pictures of the couple are taken by a professional photographer who dictates them their part: "Would the groom raise his left shoulder? Chin up. Smile. Show your white teeth. Like you love each other," he commands, acting like a stage director and pointing at the theatricality and artificiality of the couple they are supposed to embody. Then, guests to the banquet barely know the couple and were invited on command by the Chinese restaurant owner. The norm of a traditional banquet to celebrate a union is thus denounced.

\section{Queering Ethnicity: Offering New Perspectives in a Transnational Context}

22 A parallel between queer and ethnic issues can be drawn from this transgression of norms. This concept of queer allows to offer new definitions of Chinese Americans, and in our case those of second generation who do not want to conform to the norms of American mainstream society nor to those of their ethnic community of descent, this movie constitutes a transgressive stance on the part of Ang Lee, who articulates the concepts of "queer" and "masquerade" in order to denounce the artificiality of social and sexual norms. More than just denouncing, this movie reappropriates sexuality as a form of empowerment: queer and marginal characters are visible, sexually marginal yet Wai Tung eventually comes out-though partially-to his parents. Another instance of sexual empowerment shown with irony is to be found during the banquet, when some of Simon and Wai Tung's friends or colleagues comment upon the fact that Chinese guests are not the last ones to laugh, drink and be loud: "God, and I thought the Chinese were meek, quiet, math whizzes." To this a Chinese guest replies: "You're witnessing the results of 5,000 years of sexual repression." This use of humor mixed with irony is thus a means of claiming sexual margins, mocking American clichés of the Chinese as being silent, submissive and inoffensive. As William Leung (2008: 30) analyses: "the humor derives from the misunderstandings, cross-purposes, and foiled plans of ordinary people embroiled in slightly unordinary situations." And indeed, the wedding banquet in which Wai Tung is trapped is the stage on which he loses control of his seemingly perfect plan to please his parents, as well as an event during which everything he had not foreseen happens: getting drunk, losing control, getting Wei Wei pregnant.

Interestingly enough, the wedding banquet is "a symbol of both the Chinese cultural emphasis on rites (doing the right thing the right way), and the Chinese cultural emphasis on familial continuity (perpetuating the bloodline through generational succession)" (Leung 2008: 29). Could it be this pressure of heteronormativity that nevertheless led Wai Tung to play the part of the joyful groom to the point of ending 
drunk during the banquet? During the wedding night, Wei Wei, attracted to Wai Tung, makes a first move to which the young man is not indifferent, and the two inebriated protagonists have sex, which will result in an unexpected pregnancy. This pregnancy will give way to a new family configuration: that of co-parenting and homoparenthood, a transgressive stance in the 1990s. Here, Chinese American sexuality and parenthood are no longer defined along the axis of heterosexuality, nor is masculinity equated with heterosexuality.

However, we must concede that homosexuality here is shown as non-threatening, even "sanitized," claimed Peter X. Feng in his work Identities in Motion (Feng 2002a: 184), where he analyzes Ang Lee's stance: “The Wedding Banquet renders homosexuality safe for multicultural consumption, permitting homophobic audiences to overcome their ethnic/cultural differences and unite on the importance of the nuclear family" (185). If The Wedding Banquet is transgressive, how can it render homosexuality safe and answer nuclear family expectations? An analysis of the ending of the movie allows to make sense of this seeming contradiction. Indeed, Wai Tung swears to his mother that he will never tell his father that he is gay, thus allowing the pretense of a traditional nuclear family. As for Simon, he swears to Wai Tung's father that he will never tell Wai Tung his father knows they are gay, thus allowing the Gaos to pretend Wai Tung and Wei Wei are a traditional couple and Simon just a friend. Consequently, as the Gaos are about to leave the country and bid farewell, there is no mention of the co-parenting situation. However, the way of filming the scene reveals how this reconfiguration takes place: Simon, Wai Tung and Wei Wei are all gathered in an embrace, which is symbolic of this new extended family. The gay couple is thus subordinated to the injunction of filiation, but the configuration still represents a transgression of heteronorms and traditional understanding of masculinity and fatherhood.

Despite this ambivalent ending, this movie reconfigures what it means to be a man. Masculinity is not equated with heterosexuality, contrary to the homophobic prejudice according to which gay men are devoid of virility, Asian gays further criticized for being even more submissive. It also gives room for a new family reconfiguration, and gives visibility to homosexuality and Asian homosexual characters. It also denounces the heterosexual norms and the heteronormative image of masculinity. The Wedding Banquet gives voice to queer Chinese Americans, and departs from the norms of the Chinese American model minority stereotype, all silent and assimilated in the heteronormative mainstream. Nonetheless, due to a transnational audience, Ang Lee limited the representation of Chinese American queers to that of a mainstream gay man, which is a limited transgression in regards to the large panel of LGBTQ and Asian identities, yet one that can be well understood in the context of the 1990s, when movies displaying homosexual characters remained marginal and part of the independent movie circuit. However, as William Leung argues in his analysis of Lee's queer movies: "Lee's appropriation of the domestic-romantic comedy in The Wedding Banquet and the classical-humanist tragedy in Brokeback are examples of the artistic synergy of queer and straight, rather than political capitulations of queer to straight" (Leung 2008: 27). As such, Leung analyzes Lee's cinematic strategies and points to the fact that:

[L]ike all comedies of errors, The Wedding Banquet has an ironic twist near the end that ensures the story reaches a happy resolution. [...] [T] he resolution is brought home by something other than the radical morality of queer politics defeating Confucian xenophobia [...]. In fact, it is the bedrock of Chinese culture-the father's paramount esteem for familial unity and continuity-that finally becomes the agent 
for healing the potential disruption and enables a new kind of family to emerge.

(Leung 2008: 31)

This happy resolution is based on the tacit contact to respect a code of silence: no one talks about homosexuality, parents pretend nothing happened, and thus filiation can be maintained. On the contrary, in Red Doors, Georgia Lee condemns the notion of silence, which leads Ed to leave his family, his suburban lifestyle, and join a congregation of Buddhist monks. And it is that said silence that prevents him from definitely coming home to his wife and daughters. If those two movies have a lot in common, whether it be feeling marginal in a straight world, the topos of the cultural and generational gap, the stereotypes they try to deconstruct, the two movie directors do not intend to reach the same reconciliation.

We will now see that movie director Georgia Lee depicts the failure of American patriarchy through a subtle queering of social and ethnic issues, while also catering to the taste of a large mainstream audience.

\section{Queer Displacement: Red Doors (2006) as the Ethnic Indictment of Asian American Masculinity and Nation}

\section{Family Dynamics: Debunking Stereotypes}

First feature film by movie director Alice $\mathrm{Wu}$, Red Doors tells the story of a middle-class suburban Asian American family. On the surface, the characters appear as very stereotypical: the first generation, here the mother, May-Li Wong, cooks very traditional dishes and apologizes for too salty a dish, a distinctive feature of Chinese expression of humbleness; the eldest daughter, Sam, is a successful business woman. As she is about to marry, she is torn between her parents' expectations and her own personal desires. The second daughter, Julie, is a brilliant medicine student, shy and calm, also a clear embodiment of the model minority stereotype. Only Katie, the youngest, departs from this cliché as she behaves as a typical American teenager, listening to rap music on her ipod during dinner, and practicing hip-hop dancing at school. The Wongs live in the suburbs, a sign of assimilation. However, if we look more closely, this quite traditional, normative and assimilated family, is not so stereotypical. Ed is a distant father who will suddenly disappear and leave his family, after trying to commit suicide about forty times. The daughters are not so normative either. Sam will cancel her wedding out of the blue, disaffected by her life with her Caucasian partner. As for Julie, on the surface, she looks calm and shy, yet she proves to be assertive and openly out. For instance, after having met Mia, a famous actress and flirting with her, she does not think twice before telling off a noisy journalist. When the two women take tango lessons, the coach asserts: "the man always leads, but the woman offers resistance," a very heteronormative remark at which the two women laugh, showing how inadequate and ridiculous this norm is.

If Julie seems to be the lesbian character of the movie, the queer character, in the sense of a calling into question of heteronorms, is Ed, the patriarch of the family. We will now analyze how Georgia Lee chose to use a heterosexual Chinese American male protagonist to queer ethnicity and to indict American patriarchy and masculinity, all this through the use of observational humor as well as situational irony. 


\section{Ed as the Failure of American Patriarchy} naked in the bathtub, comes as a means of referring to the symbolic emasculation of Chinese men. As a matter of fact, Katie says it is not hers, but it is not Ed's either. This all sounds like there is a penis but no man around, more so when Ed is in a situation where he has lost all trappings of what society deems masculine: in the bathtub, he is weaker, naked, more vulnerable. What is more, he cannot even commit suicide properly. Indeed, in the same extract, we can see Ed dropping the phone receiver in the water, expecting to get an electric shock, which does not occur. Once again, he has failed, even in suicide.

The second analysis we may offer is that Katie is always the one who interrupts Ed, as though the second generation were the one able to bring about change and "hope." Katie is a typical American teenager, fond of rap music, listening to her ipod at the dinner table, dressed in fashionable clothes. On the contrary, Ed is nostalgic towards his past. He watches video footage of his daughters when they were young and practicing traditional activities (Chinese dancing, playing the piano for instance), or merely calling him Daddy. Ed is lost in the memories of his past, as though he could not accept the fact of aging. His sudden retreat to a Buddhist temple is another sign of his being lost in what Benedict Anderson (1983) called "imagined communities," hopeful that this retreat and meditation will bring him the solace his suburban lifestyle cannot. 
${ }^{11}$ This retreat and defection from American suburban life denounces the failure of American heteronorms: there is no satisfaction at living the American (heteronormative) dream, that of having the spouse, children, a fancy house and a welltrimmed lawn, especially for this Chinese American father. ${ }^{12}$ Being lost in his imagined community, that of his nostalgic memories of a past when his daughters were not Americanized, spoke Chinese, in other words what a Chinese family ought to be, points at the limits of assimilation in American mainstream society. Despite the cliché of the model minority, the myth of Asian American success and ease to fit in mainstream society, achieving record SAT scores and being economically successful, being assimilated into American society and living in American suburbs is not the American dream to our character. Ed's sudden retreat to a Buddhist temple is a sign of failure. The three daughters' lifestyles also show the limits of a system presented as the norm: homosexuality wins over for Julie; Sam cancels her marriage; Katie is not the China Doll stereotype, silent and well behaved.

Lastly, Ed's absence, whether it be at the dinner table or from the various scenes shot, is a cinematic strategy to call masculinity and patriarchy into question. In fact, one day, Ed suddenly vanishes. On the first night of his absence, Katie goes to the computer room and finds the following message on the screensaver: "Gone, gone, gone beyond // Gone altogether beyond," which is a Buddhist meditation sutra. ${ }^{13}$ The family thus realizes he has gone on his own will and for good. Ed's absence is underlined through the depiction of family dinners embedded into one single shot. The same characters are present at the dinner table, Ed's seat remains vacant, and the spectator watches the days, weeks, maybe months pass by as only the characters' clothes change. The only movement visible on screen is that of the Lazy Susan spinning round, signaling the passing of time as well as the absence of change. Ed is absent yet nothing happens. This absence and this stasis offer various interpretations.

First, Ed's sudden retreat to a Buddhist temple to become a monk shows that he has given up his part as a father and a husband. He renounces his role as patriarch of the family. As his daughter Sam finds a flyer about the Buddhist monastery in the kitchen garbage, she endeavors to come and visit him and tries to coax him into coming back, offering him a video footage he has not watched yet, one where we can hear the girls call for their daddy. When she asks him: "do you want to give it another try?," Ed replies “It doesn't matter. Children grow up, parents die, it's better to just leave them alone." He quits being a Chinese American man, and now pictures himself as a Buddhist monk. He caresses memories of a happier past, illustrated by the video footage he has been watching.

This absence is also a strategy to underline the impossibility for him to be a Chinese American assimilated man, a retired man in his suburban neighborhood. During his suicide attempts, western literature proved to help him not better understand his human condition, but better help kill himself. Now, he cannot live in the American world, he is lost in this dual culture, cannot fathom his children growing up assimilated. Before meant better. His finding shelter in the Buddhist temple illustrates his calling into question of norms and heteronormativity. 


\section{The Failure of the Imagined Community} linked to Ed being lost in what he imagines being what his life ought to be. He is lost in the memories of his past, as though he could not accept the fact of aging, or being assimilated. He watches video footage of his daughters when they were young and practicing traditional activities. His sudden retreat to a Buddhist temple is a desperate attempt at reaching the solace his suburban lifestyle cannot. Interestingly enough, Katie, who is a typical American teenager, which stands in sharp contrast with Ed's nostalgic memories, is always the one who interrupts his suicidal attempts, as though the second generation were the one able to bring change or to bridge the gap between the two cultures and worlds.

Even though Ed calls his role as a patriarch into question, he is drawn back to his family, which is a sign of the failure of his imagined community. Ed comes back on the night when Ma tells a prayer-"Tonight the gates of Lost Souls close," which sounds as though she came to terms with her husband's defection..$^{14}$ The whole family seems to have accepted his absence, as they are watching video footage of their childhood while he is outside, sitting on the doorsteps. At the sound of little girls' voices calling "daddy," Ed comes to the window, through which the spectator, along with him, can see the TV screen. On screen, old footage has replaced our original characters: "daddy, daddy," the spectator can hear. We can see young Ed filming his daughters, the girls dancing, skating, a Christmas celebration, etc. These embedded screens point to the fact that Ed has come back but not as an integral part of the family, not as the patriarch. He is symbolically positioned as an onlooker, a spectator to his life. He is standing apart, the queer one, drawn to his American life nonetheless, the movie ending on this depiction. What it means to be a man, a father, a Chinese American, is presented as inaccessible to him, as though he had failed to his mission.

Just like The Wedding Banquet, Red Doors offers a reconciliatory tone to its audience. However, this reconciliation is not so clear-cut. Just like in Ang Lee's movie, the ultimate seconds of the movie shed light on the ambivalence that remains. Ed remains marginal, more so when he clings to the memories from his past. His being lost in his imagined community leads him to fail in his "real" life, to be lost and forlorn, instead of embracing his American suburban life. He stays on the doorstep, facing the difficult task or mission to reconfigure his role as a father, a husband, a man in contemporary suburban America.

\section{Conclusion}

The exploration of the tensions between race, gender and sexuality, all intertwined in stereotypes created by mainstream American society, aims at calling into question the definition of Asian American identity and the construction of American and Asian masculinity, and thus identity, what Peter Feng calls "a crisis in the definition of what it means to be American" in his work Screening Asian Americans (Feng 2002b: 1). Ang Lee plays with stereotypes of Chinese men, traditional Chinese families and representations of gay men. Wai Tung is far from the silent, obedient and passive son and partner. Presented during the very first minutes of the movie as the sporty one, practicing weight lifting, this character challenges the long history of emasculated Chinese men in

Itinéraires, 2019-2 et 3 | 2019 
the United States. Ang Lee empowers the Chinese community in the U.S., empowers Chinese men and gives voice and visibility to gays, Asian or not. On the contrary, Georgia Lee chooses to depict Ed Wong as the silent one, unable to assimilate, unfit for the suburban American life, and in some respect, emasculated. Symbolically in his bathtub when his daughter comes in, but also when he chooses to become a Buddhist monk. However, Ed Wong does not become here another stereotype of the "unassimilable alien." Georgia Lee makes her Wong family a typically American one, with its existential crisis, its taboos, silences, and hopes.

41 As such, both movies illustrate Feng's contention that "Asian American cinematic identity neither conforms to nor merely resists dominant ideology" (Feng 2002a: 5). Both movies resort to humor, irony and theatricality to tackle themes which remain taboo in Asian American communities: being gay, standing apart, and not conforming to social norms and expectations. They reclaim what it means to be a Chinese American man. Nonetheless, this new Chinese American identity, stripped of the trappings of masculinity in both an American mainstream and a Chinese conservative perspective, remains to be fully reconfigured. Being a Chinese American man remains, as such, a work in progress.

\section{BIBLIOGRAPHY}

Alba, Richard and Nee, Victor, [2003] 2005, Remaking the American Mainstream: Assimilation and Contemporary Immigration, Cambridge, MA, Harvard University Press.

Anderson, Benedict, [1983] 1991, Imagined Communities: Reflections on the Origin and Spread of Nationalism, New York, Verso.

Biggers, Earl Derr, 1925, The House without a Key, New York, Grosset \& Dunlap Publishers.

Brown, Susan K. and Bean, Frank D., 2006, “Assimilation Models, Old and New: Explaining a LongTerm Process," Migration Policy, [Online], http://www.migrationpolicy.org/article/assimilationmodels-old-and-new-explaining-long-term-process, accessed 29 November 2019.

Chang, Iris, 2003, The Chinese in America: A Narrative History, New York, Viking Penguin.

Chin, Frank et al., 1974, Aiiieeeee! An Anthology of Asian American Writers, New York, Anchor Books.

Chivallon, Christine, 2007, "Retour sur la 'communauté imaginée' d'Anderson. Essai de clarification théorique d'une notion restée floue," Raisons politiques, vol. 27, no. 3, pp. 131-72.

Daniels, Roger, 1988, Asian America: Chinese and Japanese in the United States since 1850, Seattle, University of Washington Press.

Duncan, Patti, 2004, Tell This Silence: Asian American Women Writers and the Politics of Speech, Iowa City, Iowa University Press.

Eng David L. and Hom, Alice Y., 1998, Queer in Asian America, Philadelphia, Temple University Press. 
Feng, Peter X., 2002a, Identities in Motion: Asian American Film and Video, Durham, Duke University Press.

Feng, Peter X., 2002b, Screening Asian Americans, London, Rutgers University Press.

Goffman, Erving, [1963] 1986, Notes on the Management of Spoiled Identity, New York, Touchstone.

Gopinath, Gayatri, 2005, Impossible Desires: Queer Diasporas and South Asian Public Cultures, Durham, Duke University Press.

Grant, Ulysses S., "Sixth Annual Message, December 7, 1874," The American Presidency Project, [Online], by Gerhard Peters and John T. Woolley, https://www.presidency.ucsb.edu/node/ 203757, accessed 29 November 2019.

Gyori, Andrew, 1998, Closing the Gate: Race, Politics and the Chinese Exclusion Act, Chapel Hill, The University of North Carolina Press.

Hamamoto, Darrel Y. and Liu, Sandra (eds), 2002, Countervisions: An Asian American Film Criticism, Philadelphia, Temple University Press.

HoSang, Daniel et al., 2012, Racial Formation in the Twenty-first Century, Berkeley, University of California Press.

Ledru, Juliette, 2015, Dialectique de l'américanité et de l'ethnicité dans les représentations littéraires de personnages féminins : l'assimilation à l'épreuve de la fiction sino-américaine féminine (1965-2010), Ph.D, Le Havre University.

Ledru, Juliette, 2016, "Blurred lines? The dialectics of the margins and the mainstream in The Wedding Banquet (Ang Lee, 1993) and Saving Face (Alice Wu, 2004)," in F. Chan and A. Willis (eds), Chinese Cinemas: International Perspectives, New York, Routledge, pp. 96-106.

Leng, Rachel, 2013, “Calling All 'Dragon Ladies,' 'China Dolls,' and 'Lotus Blossoms,'” Unzipped: Duke's Journal of Gender and Sexuality, vol. 3, no. 1, pp. 15-26.

Leong, Karen J., 2005, The China Mystique: Pearl S. Buck, Anna Mae Wong, Mayling Soong, and the Transformation of American Orientalism, Berkeley, University of California Press.

Leung, William, 2008, “So Queer Yet So Straight: Ang Lee's The Wedding Banquet and Brokeback Mountain," Journal of Film and Video, vol. 60, no. 1, pp. 23-42.

Lionnet, Françoise and Shih, Shu-mei, 2011, The Creolization of Theory, Durham, Duke University Press.

Marchetti, Gina, 1993, Romance and the "Yellow Peril": Race, Sex, and Discursive Strategies in Hollywood Fiction, Berkeley, University of California Press.

Omi, Michael and Winant, Howard, [1986] 1994, Racial Formation in the United States. From the 1960s to the 1980s, New York, Routledge.

Petersen, William, 1966, “Success Story, Japanse-American Style," New York Times, July 6 1966, [Online], http://inside.sfuhs.org/dept/history/US_History_reader/Chapter14/ modelminority.pdf, accessed 29 November 2019.

Riviere, Joan, 1929, « Womanliness as a Masquerade », The International Journal of Psychoanalysis, vol. 10, pp. 303-313.

Rohmer, Sax, [1913] 1994, The Insidious Dr. Fu Manchu, Project Gutenberg Etext, [Online], http:// manybooks.net/titles/rohmersaetext94fuman12.html, accessed 29 November 2019. 
Sedgwick, Eve Kosofsky, [1993] 2007, Epistemology of the Closet, Berkeley, University of California Press.

Sueyoshi, Amy, 2016, "Queer Asian American Historiography," in E. Azuma and D. Yoo (eds.), Oxford Handbook of Asian American History, New York, Oxford University Press, pp. 267-78.

Time, 2018, Time Inc, [Online], http://content.time.com/time/covers/0,16641,19870831,00.html, accessed 29 November 2019.

Tong, Benson, 2000, The Chinese Americans, Westport, Greenwood Press.

\section{Corpus}

Lee, Ang, 1993, The Wedding Banquet, [PAL, subtitled, Mono], Taiwan, USA, Universal Studio Canal Video, 106 minutes.

Lee, Georgia, 2006, Red Doors, [PAL, subtitled], USA, Warner Home Video, 90 minutes.

\section{NOTES}

1. We will use Fatima El-Tayeb's definition of queering ethnicity: "strategies of resistance to racialization that work outside the logic of ethnicity and the nation, using transgressive rather than affirmative models of identity" (Tayeb, in Lionnet and Shi 2011: 244). See also the works by Gayatri Gopinath, Impossible Desires: Queer Diasporas and South Asian Public Cultures (2005).

2. This historical and cultural background is based on an in-more depth research from my Ph.D. dissertation. See Juliette Ledru, Dialectique de l'américanité et de l'ethnicité dans les représentations littéraires de personnages féminins: l'assimilation à l'épreuve de la fiction sino-américaine féminine (1965-2010), Ph.D. dissertation, 2015. See also Roger Daniels, Asian America: Chinese and Japanese in the United States since 1850 (1988); Iris Chang, The Chinese in America: A Narrative History (2003); Andrew Gyori, Closing the Gate: Race, Politics and the Chinese Exclusion Act (1998).

3. This prejudice against Chinese women could be found at all levels of US society. Even President Grant voiced it as he stood before Congress on December 7, 1874, in order to express his support towards the Page legislation: "I call the attention of Congress to a generally conceded fact-that the great proportion of the Chinese immigrants who come to our shores do not come voluntarily, to make their homes with us and their labor productive of general prosperity, but come under contracts with headmen, who own them almost absolutely. In a worse form does this apply to Chinese women. Hardly a perceptible percentage of them perform any honorable labor, but they are brought for shameful purposes, to the disgrace of the communities where settled and to the great demoralization of the youth of those localities. If this evil practice can be legislated against, it will be my pleasure as well as duty to enforce any regulation to secure so desirable an end" (the transcript of Grant's speech can be found on the following webpage: https://www.presidency.ucsb.edu/node/203757).

4. See Omi and Winant (1986) and HoSang et al. (2012).

5. See Gina Marchetti, Romance and the "Yellow Peril": Race, Sex, and Discursive Strategies in Hollywood Fiction (1993); Benson Tong, The Chinese Americans (2000). 
6. See Patti Duncan, Tell This Silence: Asian American Women Writers and the Politics of Speech (2004).

7. This Time cover is available on the following weblink: http://content.time.com/time/ covers $/ 0,16641,19870831,00 . h t m l$ (accessed 29 November 2019).

8. Ang Lee's movie was first analyzed from the standpoint of Chineseness and identities in the chapter "Blurred lines? The dialectics of the margins and the mainstream in The Wedding Banquet (Ang Lee, 1993) and Saving Face (Alice Wu, 2004)" (Ledru 2016). My ambition then was to explore forms of marginality and the cinematic redefinitions of Chineseness in a comparative study with the movie Saving Face by Alice Wu.

9. See Joan Riviere, "Womanliness as a masquerade" (1929).

10. Civilization and its discontent by Freud, The Human Condition by Hannah Arendt, Being and Time by Martin Eidegger. There are also Dialectic of Enlightenment, by Max Horkheimer and Adorno, Grounding of Metaphysics, by Kant.

11. In both movies, Benedict Anderson's concept of imagined communities can be understood as "imaginary communities," as both movies depict Chinese communities as transformed, on the one hand to please traditional elderly views (the Gaos), on the other hand through the mind of Ed Wong who longs for a Chinese community he imagines as traditional and not so modern or assimilated. This confusion or conflation of the conceptions of "imagined" and "imaginary" when it comes to the use of Anderson's theory in literary and cultural studies is the subject of many analyzes. See for instance Chivallon (2007), in which she explores the various uses made of Anderson's concept of "Imagined Communities" and she argues: "the starting point of the theory of imagined communities is rooted in the alleged absence and void which are filled with an imaginary production" (Chivallon 2007: 155), adding: "Even if it has not been theorized as such, it is this understanding of the imaginary that seems to have prevailed in the several usages of Anderson's model, if not by Anderson himself, through some acceptations he gave to the 'imagined community,' the ones in which the nation becomes more imagined than any other social formation, due to a symbolism meant to make believe in a "deep comradeship" that did not even exist" (157).

12. One can draw a parallel with Sam Mendes's movie American Beauty (1999).

13. See Interlude Retreat, 2002, Tom Barrett, http://www.interluderetreat.com/ meditate/ppsutra.htm (accessed 29 November 2019).

14. We can hear Ma's voice over as we watch Ed leaving the temple.

\section{ABSTRACTS}

Throughout the nineteenth and twentieth centuries, Chinese American men were subjected to different forms of discrimination and exclusion. The Chinese community was construed as a bachelor community, on the outskirts of the U.S. nation-state, and its men were symbolically emasculated. Consequently, Chinese American masculinity comes both as a site of submission and resistance, in which queer Chinese Americans meet the difficult challenge to conform 
neither to the Chinese nor to the American identity that cultural representations offer.

This article explores Chinese American masculinity as a site of negotiation and resistance to such representations. To do so, we use the concept of "queer," defined by David Eng and Alice Hom as "a political practice based on transgressions of the norm and normativity rather than a straight/ gay binary of heterosexual/homosexual identity" (Eng and Hom 1998: 1). Firstly, in his movie The Wedding Banquet, Ang Lee tackles the theme of Chinese Americanness through the prism of a Chinese American closeted homosexual character. This allows us to discuss how chinese American masculinity and identity are defined, explored, and negotiated in a queer context. On the other hand, the concept of queer can also be used as a theoretical tool which allows us to explore Chinese Americans' imagined community and identity. This is done through the prism of Georgia Lee's movie Red Doors, and more especially Ed, the suicidal patriarch of the family. We thus analyze the movie's queering of ethnicity which reconfigures representations of Chinese Americans.

Durant les $\mathrm{XIX}^{\mathrm{e}}$ et $\mathrm{xx} \mathrm{e}^{\mathrm{e}}$ siècles, les Sino-Américains ont subi différentes formes de discrimination et d'exclusion. La communauté chinoise a été construite législativement comme une communauté d'hommes célibataires, en marge de l'État-nation américain, et symboliquement émasculés. Par conséquent, la masculinité sino-américaine s'est développée comme un lieu à la fois de soumission et de résistance, dans lequel les hommes et homosexuels sino-américains ne peuvent ni se conformer à l'identité chinoise que leur attribue les représentations américaines, ni à celles proposées dans les représentations culturelles chinoises.

Le présent article se propose d'explorer la masculinité sino-américaine en tant que lieu de négociation et de résistance. Nous utilisons le concept de queer, défini par David Eng et Alice Hom comme « une pratique politique ancrée dans une transgression de la norme et de la normativité et non dans une vision binaire hétéro/homo de l'identité hétérosexuelle/homosexuelle » (Eng et Hom 1998 : 1). Tout d'abord, Ang Lee traite le thème de la sino-américanité dans son film Garçon d'honneur (1993) à travers son personnage principal sino-américain et homosexuel dans le placard, ce qui nous permet d'explorer la façon dont la masculinité et l'identité sino-américaines sont imaginées, définies et renégociées dans un contexte queer. Dans un second temps, le concept de queer est utilisé comme outil théorique qui permet d'explorer les identités et communautés imaginées sino-américaines. Cela s'effectue à travers le film Red Doors de Georgia Lee, et plus particulièrement le personnage d'Ed, le patriarche suicidaire de la famille. L'enjeu est de démontrer le fait que, dans ce film, l'ethnicité en souffrance revêt une dimension queer qui permet de reconfigurer les représentations des Sino-Américains.

INDEX

Keywords: stereotypes, Chinese Americans, queer, masculinity, representations, cinema

Mots-clés: stéréotypes, Sino-Américains, queer, masculinité, représentations, cinéma

\section{AUTHOR}

JULIETTE LEDRU

Université Reims Champagne-Ardenne, CIRLEP 